\title{
C L TESTAMENTO DE LA MARQUESA DEL RÀFOL. CONCEPCIÓN CASTELLVÍ (1783-1847), UN TESTIMONIO DESCONOCIDO DEL COLECCIONISMO ARTÍSTICO A PRINCIPIOS DEL SIGLO XIX
}

MARIÁNGELES PÉREZ-MARTÍN

Investigadora independiente angelespemar@hotmail.com

\begin{abstract}
Resumen: María de la Concepción Castellví y Cardona, marquesa del Ràfol, falleció en 1847 en València dejando una gran fortuna: vínculos patrimoniales en explotación, junto a bienes muebles, plata, alhajas, su biblioteca y una importante colección pictórica. La marquesa pertenecía a la más antigua nobleza valenciana vinculada a los círculos ilustrados y a instituciones como la Real Academia de Bellas Artes de San Carlos de València. Ella misma fue gran aficionada a la pintura e ingresó como académica de mérito en la entidad a la que legó algunas obras. En este artículo ofrecemos una primera aproximación a un documento desconocido y una transcripción del inventario de la colección pictórica.
\end{abstract}

Palabras clave: Marquesa del Ràfol / coleccionismo / pintura / siglo XIX / Real Academia de Bellas Artes de San Carlos de València.

THE TESTAMENT OF THE MARCHIONESS OF RÀFOL. CONCEPCIÓN CASTELLVÍ (1783-1847), AN UNKNOWN TESTIMONY OF ARTISTIC COLLECTING AT THE BEGINNING OF THE 19TH CENTURY

Abstract: María de la Concepción Castellví Cardona, marchioness of Ràfol, passed away in 1847 in Valencia leaving a great fortune: patrimonial possessions and personal properties, silver, jewellery, her library, besides an important pictorial collection. The marchioness belonged to the oldest Valencian nobility linked to enlightened circles and institutions such as the San Carlos Royal Academy of Fine Arts in Valencia. She herself was an amateur painter and fan of painting. She was academic of merit in this entity to which she bequeathed some works. In this paper we offer a first approach to an unknown document and a transcription of the inventory of the pictorial collection.

Key words: Marchioness of Rafol / collecting / painting / 19th century / San Carlos Royal Academy of Fine Arts in Valencia.

El 10 de noviembre de 1847 fallecía en la ciudad de València "la ilustre señora Doña Concepción Castellví y de Cardona, marquesa viuda del Ràfol, a la edad de 65 años". El diario El Fénix se hacía eco de la pérdida: la "profunda sensación" que había causado su muerte se percibía en su distinguida familia y era llorada por numerosos amigos. Además, dejaba huérfanos a "pobres y desvalidos a los que la marquesa socorría con tanta caridad como benevolencia". El cronista no escatimaba elogios hacia la ilustre dama: "virtuosa, resignada, benéfica y sensible". Ensalzaba su religiosidad y paciencia cristiana, que "una larga y dolorosa enfermedad" no había podido destruir. Su muerte había sido ejemplar -declaraba el diario- y en las suntuosas exequias se había cantado la gran misa de Mozart. Tras loar a la marquesa, el obituario ponía de relieve que esta dejaba una "rica, grande y original colección de cuadros". Entre las piezas de tan destacada colección había algunas de Murillo, de Ribera,

* Fecha de recepción: 15 de abril de 2020 / Fecha de aceptación: 13 de julio de 2020. 
de Espinosa, de Joanes, y de otros artistas italianos y flamencos "de reconocido mérito y de infinito precio". ${ }^{1}$

¿Cuáles eran esas obras artísticas tan excelentes, y quién era la noble dama que había acaparado tan valiosas piezas? De eso nos ocuparemos en este texto, a partir de los datos aportados en estudios anteriores sobre la marquesa del Ràfol, ${ }^{2}$ y de la reciente localización en el Archivo del Reino de València de su testamento ${ }^{3}$ y de la venta en almoneda de sus abundantes bienes. ${ }^{4}$ El coleccionismo de arte está intrínsecamente vinculado a la historia y al estatus político, cultural y económico del lugar en el que se produce, ${ }^{5}$ es un fenómeno complejo que presenta múltiples interpretaciones. Desde la faceta de la historia del arte su interés se bifurca en dos ejes principales: por un lado, constituye el acervo cultural de una nación y es símbolo de una identidad colectiva; y por otro, existen comportamientos individuales que despiertan curiosidad pues fueron determinantes en la formación de patrimonios, o mecenas de la creación plástica. ${ }^{6}$ Sin embargo, apenas existen estudios sobre la faceta coleccionista de la aristocracia valenciana y de las piezas que acumularon a lo largo de los siglos. La escasa información publicada surge a raíz de la participación de la nobleza local en las exposiciones de finales del siglo XIX, donde prestaron sus obras para ser mostradas al público. ${ }^{7}$

Aunque los estudios sobre coleccionismo suelen centrar su atención en los sectores más influyentes de la sociedad -ocupados casi siempre por individuos de género masculino y de la nobleza-, investigaciones recientes analizan el escasamente reconocido papel de las mujeres en el ámbito del coleccionismo, patronazgo y mecenazgo artístico. Nuevos enfoques sociológicos sobre intereses culturales y gusto artístico entre los diferentes roles sociales permiten acotar un marco donde "situar los avances en el conocimiento del papel desempeñado por las mujeres dentro de las estructuras artísticas y culturales". 8 Así, además de estudiar su labor como artistas es obligado analizar su influencia en el mercado artístico y la formación de colecciones. Por eso, resulta imprescindible rescatar del olvido los nombres concretos de mujeres que desarrollaron su actividad como mecenas, patronas o donantes, y con ello completar el panorama del coleccionismo en la España del siglo XIX. En ese sentido, los archivos notariales y en espe-

${ }^{1}$ El Fénix, 111, 14-XI-1847, p. 8.

${ }^{2}$ Estudiamos la biografía de la marquesa del Ràfol en PÉREZ-MARTíN, Mariángeles. "María Concepción Castellví y Cardona, pintora, académica y coleccionista" En: HOLGUERA CABRERA, A. et al. (coors.). Coleccionismo, mecenazgo y mercado artístico en España e Iberoamérica. Sevilla: Universidad de Sevilla-SAV-Escuela de Estudios Hispano Americanos CSIC, 2017, p. 134-148.

3 ARCHIVO DEL REINO DE VALENCIA (ARV). Registros Notariales. València, 1847. Protocolo 8895.

${ }^{4}$ Las casas de subasta no existían todavía en València y el mercado artístico se surtía principalmente de las almonedas de bienes ("procedimiento económico habitual que somete a pública venta, tras el fallecimiento de su propietario, objetos de toda índole, pero también piezas puramente artísticas, previamente tasadas al objeto de saldar las deudas contraídas o para la partición de bienes"), lo que venía sucediendo desde el siglo XVII en España, como afirma CANO DE GARDOQUI GARCíA, José Luis. Tesoros y colecciones: orígenes y evolución del coleccionismo artístico. Valladolid: Universidad de Valladolid, 2001, p. 130.

${ }^{5}$ Para una aproximación al ámbito valenciano que nos ocupa véase el texto de GIL SALINAS, Rafael. Arte y coleccionismo privado en Valencia del siglo XVIII a nuestros días. València: Alfons el Magnànim, 1994.

${ }_{6}^{6}$ JIMÉNEZ-BLANCO, María Dolores. Cuadernos Arte y Mecenazgo. El coleccionismo de arte en España. Una aproximación desde su historia y su contexto. Barcelona: Fundación Arte y Mecenazgo, 2013, p. 8.

7 Algunas excepciones son los textos de Leandro de Saralegui, sobre el marqués de Montortal y la marquesa viuda de Benicarló, a inicios del siglo XX. Y los más recientes sobre los marqueses de Dos Aguas por COLL CONESA, Jaume. "Un ejemplo de la participación privada de la conmemoración en 1908 del nacimiento de Jaime l: el patrimonio del marquesado de Dos Aguas y la Colección de González Martí". En BENITO DOMÉNECH, F. et al. (com.). La Edad de oro del Arte valenciano. València: Generalitat Valenciana, 2009, p. 65-71. Así como, los apuntes sobre el mecenazgo de los condes de Parcent realizados por SAN RUPERTO, Josep. "Apuntalarse como noble: cultura, arte y mecenazgo en la Valencia del siglo XVII. Representación y perpetuidad en la familia Cernesio, condes de Parcent". En: FELIPO ORTS, A. et al. (ed.). La nobleza valenciana en la Edad Moderna. Patrimonio, poder y cultura. València: Universitat de València, 2014, p. 249-251. Y las investigaciones sobre la colección de arte de los condes de Cervellón y los marqueses de Villatorcas dadas a conocer por GIL SAURA, Yolanda. "Los gustos artísticos de los novatores valencianos en torno a 1700. La colección de pintura de los marqueses de Villatorcas", LOCVS AMOENVS, 2007-2008, n 7, p. 171-188. Estudios que introducen el coleccionismo aristocrático valenciano entre los siglos XVII y XVIII, tal como nos refiere el interesante trabajo de GARCíA MARTíNEZ, José Luis. "La configuración de una colección nobiliaria. El ejemplo de la Casa de Parcent (1656-1927)", Ars bilduma, 2016, n 6, p. 43-60.

8 ILLÁN MARTíN, Magdalena. "Coleccionismo y patronazgo artístico femenino en la Sevilla de finales del siglo XVIII". En: LORENZANA DE LA PUENTE, F. et al. (coors.). Arte, poder y sociedad; $y$ otros estudios sobre Extremadura. Llerena (Badajoz): Sociedad Extremeña de Historia, 2006, p. 109-117, p. 112. La autora reflexiona sobre el coleccionismo artístico femenino, y destaca el enfoque de estudios como el de CABELLO CARRO, María Paz. Coleccionismo americano indígena en la España del siglo XVIII. Madrid: Ediciones de Cultura Hispánica, 1989; y el de RODRÍGUEZ ALCALDE, Leopoldo. El coleccionismo pictórico en España. Santander: Fundación Marcelino Botín, 1990. 
cial las testamentarías son fuentes reveladoras al respecto y ofrecen interesantes datos sobre el coleccionismo por parte de mujeres, la mayoría vinculadas a familias nobiliarias, como en el caso que detallamos en esta investigación. Una de las pocas noticias que tenemos sobre colecciones de titularidad femenina en el ámbito valenciano de principios del XIX.

María de la Concepción Castellví y Cardona pertenecía a uno de los linajes más antiguos de la Corona de Aragón. El apellido Castellví o Castelví tuvo origen en Borgoña, sus propiedades se ubicaban en el principado de Cataluña. Después, el linaje llegó a València donde la línea enlazaba con Cerdeña. Esa primera rama fueron los condes de Carlet, de la que era descendiente la marquesa. Concepción nació el 21 de junio de 1783 en la ciudad de València, parroquia de Santo Tomás. Heredó de su padre, Miguel Castellví Ferrer La Figuera y Pinós (30-V-1754, †28-II-1810), la baronía de Alcácer y las Villas de Sartaguda y Arrubal "en Castilla la Vieja y Navarra". ${ }^{9}$ Por línea materna, la marquesa del Ràfol entroncaba con otro de los más nobles apellidos valencianos, los Folch de Cardona, y con los Catalá de Valeriola, marqueses de Nules y Quirra. Su madre, Paula Cardona Catalá Jofré y Castellví (†2-VII-1799), ${ }^{10}$ era hija de Salvador Cardona Jofré y de María Catalá Castellví Cardona Escrivá, de la familia de los marqueses de Quirra. Varios documentos de la época dejan constancia de la presencia de numerosos miembros de la saga entre la élite de la ciudad de València. El cronista Agustín Sales en sus Memorias Históricas del antiguo Santuario del Santo Sepulcro de València, incluye un "catálogo" de personas nobles que "al alistarse en esa Hermandad, desde su erección hecha el 6 de abril de 1688", apoyaron la conservación del Santo Sepulcro "en tiempos de moros". ${ }^{11}$ Ese listado confeccionado en 1746 lo encabezan varios miembros de su lina- je, entre ellos el conde de Carlet, Felipe Lino de Castellví (ca. 1675 - ca. 1740). El conde fue anfitrión de una tertulia junto al padre Tosca y Juan Bautista Corachán que constituyó el principal círculo del llamado movimiento novator o representantes preilustrados en la ciudad de València. El catálogo incluía también diversos personajes notables de los Cardona, Ferrer, Milán de Aragón, Monsoriu, Pertusa, Roca, o Mercader, apellidos relacionados con su línea de nobleza. En el listado de las "Señoras" estaban igualmente muchas damas de su entorno más cercano, lo iniciaban las condesas de Faura, la de Castellar, las de Carlet, la de la Alcudia o la de Sumacárcel, para continuar con apellidos como Vives, Escrivá, Jofré, o Montalto, también vinculados al linaje. La última en adherirse a la causa benéfica era Doña Pascuala de Cardona.

Algo similar observamos en el listado de Caballeros que integraban la Real Maestranza de Caballería de València en 1747. Tras haber sido suspendida la actividad durante la Guerra de Sucesión, algunos miembros de la Corporación, junto a descendientes de los fundadores, restablecían "su primitivo esplendor". ${ }^{12}$ Entre los sesenta y cinco nombres se enumeran prácticamente todos los apellidos anteriormente citados, incluyendo al abuelo de la marquesa. Joaquín de Castellví y de la Figuera, señor de Benafer, fue un hombre ilustrado, autor del libro Mercurio sacro y poético. ${ }^{13}$ Una extensa crónica que recoge lo acontecido en el certamen literario celebrado en 1745 en las Escuelas del Seminario de Nobles de San Ignacio de València, donde él mismo fue alumno. Este tipo de eventos tuvieron un papel relevante en el programa de enseñanza de los colegios de la Compañía, pues mientras se cumplía el propósito catequético practicaban el arte de la oratoria. Según recoge su autor, en 1745, participaron personalidades literarias como el jesuita Antonio Exime-

\footnotetext{
9 PÉREZ DE AZAGRA Y AGUIRRE, Antonio. "Los Proxitas". Revista de Historia y de Genealogía, 1930, septiembre-octubre, $n^{\circ} 23$, p. 356-389.

10 Miguel Castellví Ferrer y Paula Cardona Catalá se casaron el 11 de octubre de 1780 en la parroquia de San Andrés de la ciudad de València. Otras fuentes la citan como Pascuala en lugar de Paula.

11 SALES, Agustín. Memorias Históricas del Antiguo Santuario del Santo Sepulcro de València. Su autora D. Agustín Sales, presbitero de la Iglesia de San Bartholomé, Doctor Theologo de la Universidad de València, Chronista de la misma Ciudad, i Reino, i Académico Valenciano. València: Oficina de Josef Estevan Dolz, Impresor del S. Oficio, 1746.

12 REAL MAESTRANZA DE CABALLERÍA DE VALÈNCIA. "La primera suspensión 1703-1747" (en línea). En: http://www.rmcv.es/historia/la-primera-suspension (Fecha de consulta: 29-III-2020).

${ }^{13}$ CASTELLVÍ Y LA FIGUERA, Joaquín. Mercurio Sacro y Poético en el qual se contienen algunas noticias tocantes a los progresos que en Virtud y Letras hace la Juventud Valenciana, que cursa las Escuelas del Seminario de Nobles de San Ignacio. Acreditados en las Solemnes Fiestas, y Certámen Literario del año escolar 1745. Su autor Don Joachin Castelví y La Figuera, Señor de los Lugares de Benafer, Arrubal, Sartaguda y Ragudo, alumno de las mismas Escuelas. València: Oficina de Joseph Estevan Dolz, Impresor del S. Oficio, 1745.
} 
no. ${ }^{14}$ También por línea materna, los Cardona tuvieron peso cultural en la ciudad, José Cardona y Pertusa, bisabuelo de Concepción, era un buen conocedor del francés y del castellano, como muestra su traducción de una Vida del Cardenal Richelieu de autor francés desconocido, en tres tomos. ${ }^{15}$ José Cardona participó en academias y justas poéticas en la València de finales del siglo XVII y comienzos del XVIII. Consta su presencia en la Academia a las Señoras en 1698, en la Academia Valenciana en 1703 y en los actos extraordinarios de 1704. En ellas tocó el archilaúd y disertó sobre la ciencia matemática. ${ }^{16}$

Del mismo modo, muchos miembros del linaje Castellví estuvieron vinculados a los orígenes de la Real Academia de Bellas Artes de San Carlos de València. Algunos de sus familiares se encuentran entre los más antiguos académicos de Honor. Como su abuelo, Joaquín Castellví y la Figuera, que ingresó en la institución en 1768, apenas cinco meses después de su fundación. ${ }^{17}$ También el hijo de este, Miguel Castellví Ferrer -padre de Concepción- sería nombrado académico años más tarde, el 6 de diciembre de 1807. Incluso ella misma. ${ }^{18}$ Concepción Castellví se convirtió en una de las primeras mujeres en obtener el título, el 2 de diciembre de 1810. En su caso, como era habitual para damas aficionadas a la pintura, ingresó como académica de mérito; tras presentar a la Junta un "pastel hecho de su mano que representa al Beato Nicolás Factor de medio cuerpo con su marco de oro y cristal". ${ }^{19}$ Visto su mérito -según quedó reflejado en el acta-, consiguió el voto unánime de los profesores y académicos de la Junta.

El 15 de octubre de 1815, Concepción Castellví y Cardona unió la nobleza de su estirpe a la aristocracia liberal de la época al casarse con Antonio Almunia Rodríguez (València, 16-IX-1778 - València, 1841), marqués del Ràfol. Capitán de caballería, maestrante de València y caballero de la Orden de Montesa. ${ }^{20}$ El matrimonio Almunia Castellví fijó su residencia en el histórico palacio familiar de los Cardona en la ciudad de València. ${ }^{21}$ Años después del nombramiento de su esposa, el marqués del Ràfol también ingresó como académico de honor en la Real Academia de Bellas Artes de San Carlos, el 11 de octubre de 1823. Incluso se ofreció a financiar los premios anuales de la institución. En 1834, Almunia fue nombrado prócer del Reino junto al marqués de Jura Real. Aunque no llegó a tomar posesión del cargo por enferme-

${ }^{14}$ Antonio Eximeno y Pujades (València, 1729 - Roma, 1809) fue escritor jesuita, musicólogo, matemático y filósofo. Estudió en la Universitat de València y fue profesor de retórica en el Seminario de Nobles. Véase: HERNÁNDEZ MATEOS, Alberto. "Estudio Preliminar". En: EXIMENO, A. Del origen y reglas de la música con la historia de su progreso, decadencia y restauración. Madrid: Editorial Verbum, 2016, p. XXI.

${ }^{15}$ El texto original pudo ser el de Charles VIALART DE SAINT-PAUL. Histoire du ministere d'Armand lean du Plessis, cardinal duc de Richelieu..., 3 vols. París: Compagnie des libraires du Palais, 1665. Aunque en los repertorios clásicos se cite como la traducción de un anónimo, sabemos que la censura en el siglo XVII era habitual y en muchas portadas no se expresaba la autoría, como ocurre en el libro de Charles Vialart.

${ }^{16}$ MAS I USÓ, Pasqual. "Introducción. Noticia Bio-Bibliográfica de los Académicos". En: ORTí Y MOLES, J. Academia a las señoras (1698). Kassel: Edition Reichenberger, 1994, p. 49.

17 El de Joaquín Castellví y la Figuera fue uno de los primeros títulos de académico de honor otorgado el 17 de julio de 1768. La Academia de San Carlos fue creada oficialmente el 14 de febrero de 1768.

${ }^{18}$ La participación de las mujeres en las Academias artísticas en época ilustrada fue más numerosa de lo que habitualmente se ha considerado, en València fueron cuarenta las que obtuvieron el título académico de mérito. Un título que al menos nominalmente era el mismo que obtenían los artistas y profesores, aunque ellas no podían estudiar en las aulas de la institución. Sobre el ingreso de mujeres en las academias de arte en España véase nuestro reciente estudio PÉREZ-MARTíN, Mariángeles. Ilustres e ilustradas. Académicas de Bellas Artes ss. XVIII-XIX. València: Tirant Humanidades, 2020, p. 163-169. Para examinar la situación de la mujer artista en el siglo XIX en España, el texto pionero de DIEGO OTERO, Estrella de. La mujer y la pintura del XIX español. Cuatrocientas olvidadas y algunas más. Madrid: Cátedra, 1987.

19 ARCHIVO DE LA REAL ACADEMIA DE BELLAS ARTES DE SAN CARLOS DE VALÈNCIA (ARASC). Libro de Individuos desde su creación 1768-1847, p. 140.

20 ARCHIVO HISTÓRICO NACIONAL (AHN). OM-Caballeros_Montesa, Mod. 63. En abril de 1827, cuando obtuvo el Hábito de Caballero de la Orden de Montesa, era capitán retirado de Caballería. Antonio Almunia Rodríguez era hijo de Antonio Almunia Judici Isco (Benigànim, 12-III-1719, València, 1-X-1811) y de su segunda esposa, Julia Rodríguez Mergelina, natural de ViIlena (†1-X-1792), marqueses del Ràfol. Sus abuelos paternos fueron: Francisco Pascual Almunia Isco y Quincoces, natural de Benigànim, y Bernarda Judici de Acharte y Blanes, natural de Alcira. Y los abuelos maternos: Pedro Rodríguez de Navarra, natural de Villena, y Juliana Mergelina, también de Villena.

21 El Palacio de los Cardona estaba en la denominada entonces calle del Ave María, número 15, de la ciudad de València. Actualmente el edificio, ubicado en la calle Marqués de Dos Aguas, lo ocupa el Hotel Inglés, y antes de este el Hotel de Roma. En esa misma calle estaba la desaparecida Casa de los Castellví, que dio el nombre original a la calle Castellvins, después llamada Argüelles y Canalejas. 
dad. ${ }^{22}$ El marqués murió en València en 1841, sin descendencia, dejando a su esposa como propietaria de su patrimonio y fortuna. Así pues, la marquesa dispuso en un testamento otorgado el 5 de mayo de 1847 ante el notario Juan Genovés Causa en la ciudad de València cuál sería cuando ella falleciera el destino de los bienes propios y de los que heredó de su marido. ${ }^{23}$

El "Testamento de la Ilustre Señora Marquesa Viuda del Ràfol" comenzaba estipulando el modo en el que debía ser enterrado su cadáver. Según anotaba el escribano en las cláusulas que siguen, "Doña María de la Concepción Castellví y de Cardona, baronesa de Alcácer, señora de Benafer y Herragudo, dueña propietaria de Arrubal y Sartaguda en Castilla la Vieja y Navarra" estableció así los detalles del funeral:

2. Otrosí: quiero que mi cadáver sea vestido con hábito como el que usan las religiosas del convento de la Santísima Trinidad extramuros de esta población, y que se le sepulte en el mismo nicho o casilla que tengo comprado en el Cementerio General de esta ciudad al lado de la que está depositado el cadáver de mi difunto marido.

3. Otrosí: quiero que mi funeral y entierro se hagan cuarenta y ocho horas a lo menos después de mi fallecimiento, y se celebre aquel de la clase de general con asistencia de todo el clero de las Parroquias de Santo Tomás apóstol y de los de las Parroquias de San Andrés también apóstol y San Martín de esta ciudad, con misa cantada de cuerpo presente, pero sin catafalco ni túmulo; y que acompañen mi entierro doce niños de la Casa de Misericordia, doce de la Beneficencia y doce del Colegio de San Vicente Ferrer.

Continuaba el testamento detallando los bienes que legaba a los distintos beneficiarios. Los marqueses del Ràfol profesaron una ferviente religiosidad en vida y pertenecieron a múltiples entidades benéficas a las que ella no olvidó en su herencia. Así, donaba "por una sola vez cien libras moneda del Reino para la conservación de los Santos Lugares de Jerusalén". También, por una sola vez, legaba cien reales de vellón a los establecimientos siguientes: Hospital General, Hospicio de Nuestra Señora de la Misericordia, Casa de Beneficencia, Colegio de Niños huérfanos de San Vicente Ferrer y Asociación de Nuestra Señora del Santo Zelo y Esperanza de la Salvación de las almas de esta ciu- dad. Asimismo, asignó para "sufragio de su alma y las de los demás fieles difuntos de mayor obligación" la cantidad de setenta mil reales de vellón. Entre los colectivos a los que favorecía la marquesa en su legado había dos comunidades de monjas: las Religiosas de San Cristóbal de la ciudad de València y la de Religiosas Agustinas de Benigànim (población de origen de la familia de su difunto esposo, donde los marqueses residían durante la temporada de verano). A ambas congregaciones les donaba doscientas libras moneda del Reino "para que las invirtiera[n] en lo que más necesiten". Además, fundaba una administración, a cargo del mismo administrador, José María Vera, con todos los bienes patrimoniales de su difunto esposo no provenientes de vinculaciones. Según especifica el apartado 39:

\begin{abstract}
...destinada principalmente a conservar dichos bienes por espacio de cuarenta años contados desde el día de mi fallecimiento para que en el caso de obtenerse en dicho tiempo el decreto de beatificación de la Venerable madre Inés de Benigànim, se vendan los expresados bienes y se invierta su producto en costear y satisfacer los gastos que se quedasen a deber de la causa de la beatificación, en vestir la imagen y en construir una capilla y un altar en el Convento de Religiosas Agustinas de Benigànim, si entonces existe, según el diseño que estas tienen y si dicho convento no existiese se harán en la capilla y altar en la Iglesia donde se custodie el cuerpo de la expresada venerable madre Inés. Si obtenido el decreto de su beatificación, no pudiese tener efecto lo que dejo dispuesto por no permitirlo las leyes órdenes o disposiciones entonces vigentes los referidos bienes pasarán a los hijos de Don Luis Melo de Portugal y Almunia, en los términos que luego explicaré. ${ }^{24}$
\end{abstract}

Transcurridos esos cuarenta años desde su muerte las fincas que constituían el legado no se habían podido vender por dificultades de titulación, según decía la prensa. ${ }^{25}$ El cronista dudaba que pudiera llevarse a cabo la canonización prevista para el 6 de enero de 1888 pues la solemnidad que requerían los actos suponía unos gastos considerables: fiestas en Benigànim y València, imágenes de la beata y un altar en la iglesia del convento. No obstante, los herederos y administradores se ofrecieron a anticipar el capital necesario. La beatificación se llevó a cabo el 26 de febrero de 1888 por el Papa León XIII. En agosto de 1896 se trasladó el cuerpo de la Beata

\footnotetext{
22 SENADO DE ESPAÑA (en línea). "Expediente personal del Prócer Marqués de Ràfol, D. Antonio Almunia (no juró)". En: http:// www.senado.es (Fecha de consulta: 30-III-2020).

${ }^{23}$ ARV. Registros Notariales. Juan Genovés Causa. València, 1847. Protocolo 8895. "Testamento de la marquesa del Ràfol, 5 de mayo de 1847", fol. 762.

${ }^{24}$ ARV. Protocolo 8895, fol. $762 \mathrm{v}$.

25 La llustración católica, 5-X-1887, p. 12.
} 
Sor Josefa María de Santa Inés ${ }^{26}$ hasta la nueva capilla construida en el convento de Madres Agustinas de Benigànim. El mismo convento había recibido, el 19 de julio de 1848, otra donación mandatada en el testamento de la marquesa del Ràfol, que consistía en "los damascos existentes en su casa y en la casa familiar de Benigànim". ${ }^{27}$ El conjunto fue tasado en Inventario por 2.240 reales de vellón.

El cómputo general de los bienes muebles que la marquesa acumulaba en su vivienda en el momento de su muerte ascendía a 255.304 reales de vellón $(\mathrm{rs} / \mathrm{v}) .^{28}$ Enseres personales que comprendían caballerías, tartanas y landós; mobiliario, objetos de cocina y ropa de hogar; paños, puntillas y tejidos; vestidos, abanicos y pañuelos; objetos de escritorio y tocador; plata y joyería; casullas, objetos de culto y misales; libros, estampas, esculturas y cuadros. Todos ellos eran tasados en presencia del administrador y los herederos, según refleja el Inventario. Esos precios sufrieron fluctuaciones en las cifras de venta en almoneda, casi siempre al alza. Llama la atención el porcentaje de capital que la marquesa del Ràfol había invertido solamente en mantelerías y ropa de cama, un importe de 26.647 rs/v. También los noventa abanicos acumulados que alcanzaban un valor total de $1.822 \mathrm{rs} / \mathrm{v}$, llegando alguna unidad a los $140 \mathrm{rs} / \mathrm{v}$. Frente al cuantioso coste del ajuar doméstico observamos que su nutrida biblioteca era tasada en 6.420 rs/v; sumando el conjunto de libros que la formaba unos setecientos títulos y más de mil volúmenes. ${ }^{29} \mathrm{El}$ minucioso Inventario supone una preciosa instantánea del contenido de una vivienda aristocrática a mediados del siglo XIX. ${ }^{30}$ La descripción de cada una de las estan- cias, con los utensilios de uso doméstico y objetos suntuarios que contenían, son una fuente para el estudio de la vida doméstica. Es curiosa la diferencia proporcional existente con los productos de consumo actual y lo que debía suceder en esa época. Por ejemplo, "dos sofás con almohadones, cinco sillas y una mesa de pino", eran tasados en $72 \mathrm{rs} / \mathrm{v}$; mientras un tonel con vino se estima en $60 \mathrm{rs} / \mathrm{v}$ y "ciento veintiséis botellas con vino de varias clases" se valoran en $400 \mathrm{rs} / \mathrm{v}$. Aunque en una primera lectura de los datos de las múltiples jornadas de almoneda vemos que su valor de venta fue muy superior, algunas botellas se vendieron por $60 \mathrm{rs} / \mathrm{v}$. La contraposición de los precios de inventario y almoneda, el análisis pormenorizado que identifique los objetos y el estudio de su disposición en las estancias descritas excede los límites de este texto, pues la almoneda se extendió durante meses.

Respecto a los bienes más valiosos, en primer lugar, estaban los vínculos patrimoniales. Numerosos inmuebles y tierras en explotación en la ciudad de València, sobre todo, en la zona de Campanar, y en muchas otras poblaciones valencianas como Alcácer. También en localidades del Alto Palancia, Benafer y Herragudo (Castellón), y en los términos de Sartaguda y Arrubal, en Navarra y la Rioja actual. Las personas que crearon esos vínculos, ascendientes de la estirpe de los marqueses del Ràfol, se mencionaban junto al patrimonio correspondiente: Miguel Sanoguera, barón de Alcácer; Francisco Gerónimo Artés de Albanell; Jayme Sanz Cutanda; Mariano Juan Bas; y Carlos Ramírez de Arellano. ${ }^{31}$ Las propiedades incluían hornos de pan, molinos, derechos de riego y viviendas en renta,

${ }^{26}$ GUINOT FERRI, Laura. Santidad femenina, curación milagrosa y religiosidad popular en la Valencia moderna: la beata Inés de Benigànim. Tesis Doctoral, Universitat de València, 2019.

27 El notario registró el acto de entrega a las monjas: "Quiero que los damascos que existiesen en mi Casa Mortuoria y en la de Benigànim al tiempo de mi fallecimiento se entreguen a la Comunidad de Religiosas Agustinas Descalzas de Benigànim, a la cual los lego". Que practicado el Inventario de los bienes muebles y ropas existentes en la Casa Mortuoria de dicha Señora en esta ciudad, por jornada antemí a diez y nueve de mayo último, se anotaron entre otras bajo los números: 949 . Una cortina grande de damasco carmesí / 950. Doce cortinas de damasco de varios tamaños / 951 . Cinco pedazos de damasco / 952. Treinta y tres fundas de asientos de sillas de damasco carmesí usadas / 953. Tres ruedos de cama de damasco / 954 . Cinco cortinas de damasco azul usadas / 955. Seis cortinas de damasco color de barquillo usadas / 956. Varios pedazos de damasco / 957. Un lío con treinta y siete varas y tres palmos, y otro de cuarenta y dos varas damasco verde en varios pedazos / 964 . Cinco pabellones de damasco verde usado con fleco encima de los balcones y puertas de la sala / 965 . Cuatro pabellones de damasco color de barquillo. ARV. Registros Notariales. Protocolo 8896. "Carta de pago La Comunidad de Religiosas Agustinas de Benigànim a la Testamentaría de la Iltre. Sra. D. ${ }^{a}$ Concepción Castelví", fol. 1402v. València, 19 de julio de 1848.

${ }^{28}$ Utilizamos la abreviatura [rs/v] para referirnos a los reales de vellón.

${ }^{29}$ La extensa biblioteca reúne abundantes textos religiosos, libros de historia y mitología, junto a otros de agricultura, jardinería o arte. Una importante colección -pendiente aún de análisis- cuya titularidad pudo ser compartida con su esposo, heredada de su padre o abuelo, pero que muy probablemente recoge las inquietudes intelectuales de una mujer ilustrada en la València de principios del siglo XIX.

30 Sobre lujo y vivienda en el siglo XIX véase HEREU I PAYET, Pedro. "Lujo e interior burgués en la segunda mitad del siglo XIX", Anales de la arquitectura, 1990, $\mathrm{n}^{\circ}$ 2, p. 107-118; y RIDAURA CUMPLIDO, Concha. Vida cotidiana y confort en la Valencia burguesa, 1850-1900. València: Generalitat Valenciana, 2006.

31 Queda pendiente su identificación y desentrañar la línea hereditaria, algo que requiere un estudio aparte. 
y eran valorados en una primera estimación por un monto total de $1.825 .555 \mathrm{rs} / \mathrm{v}$.

En cuanto a los objetos suntuarios que citábamos anteriormente se encuentran abundantes piezas de plata, cuberterías, bandejas, candeleros, escribanías, y hebillas, con una tasación estimada de $25.585 \mathrm{rs} / \mathrm{v}$. Destacan entre las piezas más valiosas un cáliz de plata valorado en $734 \mathrm{rs} / \mathrm{v}$, "un conjunto de ocho candeleros" en 2.387 rs/v, "una cubertería de doce piezas con sus cuchillos" en 1.082 rs/v, y otra igual por $1.542 \mathrm{rs} / \mathrm{v}$. Un ajuar cuyo valor se sitúa muy por encima del precio de las joyas de la marquesa, justipreciadas en 15.506 rs/v. Pendientes, cadenas de oro, sortijas, alfileres y medallones, los más preciados una "sarta de perlas finas con candado de diamantes rosa" por $1.620 \mathrm{rs} / \mathrm{v}$, un "ramillete de brillantes para la cabeza" por $1.320 \mathrm{rs} / \mathrm{v}$, y un "cintillo de brillantes" por $1.500 \mathrm{rs} / \mathrm{v}$.

Sin embargo, el conjunto más extraordinario de sus bienes era la colección pictórica. Tal como afirma el cronista en el obituario con el iniciábamos este texto, era "una colección digna de un gran príncipe". ${ }^{32}$ Según el mismo diario, varios personajes extranjeros habían puesto mucho empeño hacía años para comprar "un hermoso original de Ribera" que los marqueses del Ràfol jamás consintieron en vender. Concluía el cronista expresando su deseo de que la marquesa no hubiera olvidado en su testamento destinar de "manera correspondiente" a las iglesias o a la academia parte de su legado. $Y$ anunciaba que estaba el autor elaborando un catálogo de tan interesantes pinturas, que publicaría El Fénix "para conocimiento de los apasionados". Aunque no hemos podido localizar ese catálogo, el reciente hallazgo del Inventario de los bienes de la marquesa del Ràfol donde se describen esas obras tan preciadas aporta interesante información sobre la colección. Es cierto que las descripciones son a veces escuetas y en muchos casos no se especifica la autoría. ${ }^{33}$ Entre las obras inventariadas estaban las que la marquesa dejó a sus familiares y las que, tal como imaginaba el articulista de El Fénix, había legado a la Academia de San Carlos de la que fue miembro. Esos beneficiarios aparecen detallados en su testamento:
18. Otrosí: quiero que los cuadros pintados al óleo que representan San Sebastián, el Sacrificio de Isach, San Pedro Pascual de Valencia celebrando el Santo Sacrificio de la Misa, y la Virgen de cuerpo entero, obra de Murillo que está al lado del cuadro de San Sebastián, se entreguen a la Academia de Nobles Artes de San Carlos de esta ciudad, siendo condición expresa que si esta Corporación quisiera desapropiarse de ellos o tratara de apropiárselos el Gobierno, no tenga efecto este legado $y$, volviendo por consiguiente a entrar en mi testamentaría, serán para la Catedral de esta ciudad en iguales condiciones.

19. Otrosí: Lego a mi sobrino Don Pascual Mercader y Roca, marqués de Malferit, los dos cuadros que representan los dos filósofos y el que está en medio de ellos que representa la Virgen de la Luz.

20. Otrosí: Lego a Doña Dolores Alcedo, esposa del Señor Don Pascual Mercader y Roca, marqués del Malferit, el ramo de brillantes que tengo para la cabeza, un hilo de perlas aljofares, la pintura de la Virgen de los Desamparados que está en el cuarto de papel color de rosa, una cadenita de oro que tiene a los cabos una borlita de lo mismo, y un cubierto de ágata con su salero que todo está en una caxita.

21. Otrosí: Lego a D. ${ }^{a}$ Concepción Gual y Vives una sortija de brillantes que tiene cinco en fila, el abanico mejor que tengo de marfil, y prevengo que se le devuelva la imagen de escultura de la Beata Catalina Tomás por ser suya, como también el cuadro del Descendimiento de Nuestro Señor Jesucristo de la Cruz que está en el cuarto del oratorio.

22. Otrosí: Lego a Don Joaquín Mercader y Roca, doce cubiertos de plata con sus cuchillos, y la pintura o cuadro de San Joaquín que tiene en brazos a la Virgen Dormida.

23. Otrosí: Lego al Excmo. Señor Don Pascual Fenollar, conde de Olocau, los cuadros que representan, el uno el Calvario pintado por el Vasari, y el otro una liebre.

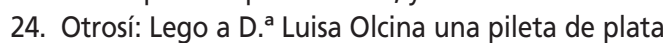
que es un ángel con hisopo colocada a la cabeza de mi cama y seis cubiertos de plata con sus cuchillos. ${ }^{34}$

Los herederos testamentarios y albaceas del resto de los bienes de la marquesa fueron tres familiares suyos. En primer lugar, y como mayor beneficiario, Pascual Mercader Roca, marqués de Malferit. Junto a él su hermano, Joaquín Mercader Roca, $y$, por último, su sobrino Miguel Caro Baciero, a quién legó su vivienda en la calle Ave María de València y otros inmuebles. ${ }^{35}$ Pascual Mercader (1799-1867)

32 El Fénix, 111, 14-XI-1847, p. 8.

33 En el anexo se transcribe la descripción de las obras y su tasación. ARV. Protocolo 8896. "Segunda jornada del Inventario de los bienes de la herencia de la llustre Sra. D. ${ }^{a}$ Concepción Castelví", fol. 214v.

34 ARV. Protocolo 8895, fol. 761v.

35 Casi todos los días durante la realización del Inventario de la marquesa, así como en muchas jornadas de almoneda, estuvieron presentes el marqués de Malferit, su hermano Joaquín Mercader, y José Caro y Caro en representación de su hijo Miguel Caro Baciero, como herederos y albaceas testamentarios. 
había heredado de su madre, María Ignacia de Roca y Castellví, el título de VIII marqués de Malferit tras la muerte de esta en agosto de $1834 .{ }^{36}$ María Ignacia era hija de Salvador Roca y Pertusa, Malferit y Milán de Aragón (1743-1820), V marqués de Malferit y VII conde de Buñol, y de Rafaela de Castellví y Ferrer de Proxita Figueras y Pinós -hermana de Miguel Castellví Ferrer, padre de Concepción Castellví Cardona (marquesa del Ràfol)-. Pascual Mercader Roca obtuvo en 1862 licencia para contraer matrimonio con Dolores Tudela y Gallinas, ${ }^{37}$ pero antes estuvo casado con Dolores Alcedo -a quien legaba la marquesa del Ràfol en 1847 algunos bienes en su testamento-. Pascual Mercader falleció el 29 de abril de 1867.38 Por su lado, Miguel Caro Baciero, Caro Fernández de Córdoba (6-XII-1841, †7III-1929) era hijo de José Caro y Caro, Fontes y Ortiz (11-II-1801, †28-v-1856), perteneciente al linaje de los marqueses de la Romana, y de María Baciero Fernández de Córdoba, Bryas Ferrer (18-VII-1792, $\nmid 10-$-1854), de la familia de los barones de Petrés por línea paterna, y de la de los condes de Peñalva por la materna. Respecto al conde de Olocau, en 1847 debía ser Pascual Fenollet y Crespí de Valldau$\mathrm{ra}^{39}$ el cual falleció sin descendencia y en 1889 el título pasó a su sobrina María del Carmen Crespí de Valldaura y Caro. ${ }^{40}$ También recibió parte de los bienes, el heredero al título de marqués del Ràfol, su sobrino y ahijado Luis Melo de Portugal Almunia, Rocha y Sancho. Nacido en València en 1770, fue bautizado en la parroquia de San Esteban el 9 de marzo. Era hijo de Pablo Melo de Portugal, teniente agregado al Estado Mayor en València, marqués de Villescas y de Barajas de Melo, y de su esposa
Pascuala Almunia Sancho. Pascuala heredó el marquesado del Ràfol a la muerte de su hermano Antonio Almunia Rodríguez en $1841 .{ }^{41}$

En cuanto a los cuatro cuadros que dejó como legado a la Academia de San Carlos, consta que la entrega se demoró durante varios meses. Razón por la cual los dirigentes de la institución acordaban reclamar las obras para tomar posesión de ellas. ${ }^{42}$ Por fin, el 27 de marzo de 1848, se efectuó por parte de los herederos la entrega de las obras a la Academia:

752. Un lienzo grande con marco dorado que representa un San Sebastián muerto después del martirio, obra del célebre Ribera.

738. Un lienzo grande con marco dorado que representa el Sacrificio de Isach.

755. Un lienzo grande con marco dorado que representa San Pedro Pascual en el acto de celebrar misa y al Niño Jesús ayudándosela, obra de Don Gerónimo Espinosa.

747. Un lienzo grande con marco dorado que representa una Virgen y el Niño de cuerpo entero, obra de Murillo. ${ }^{43}$

La colección de los marqueses del Ràfol estaba formada por más de doscientas piezas en el momento de la muerte de la marquesa. Un volumen considerable si lo comparamos con otras prestigiosas colecciones españolas de mediados del siglo XIX, como la de la aristócrata Bernardina María Fernández de Velasco (1815-1869), duquesa de Uceda, conformada por 253 pinturas; ${ }^{44}$ o la de Josefa Marín (1807-1871), condesa de Velle, que acumuló un centenar de pinturas y esculturas mayoritariamente de artistas coetáneos. ${ }^{45}$ Otras co-

${ }^{36}$ AHN. Consejos, 8983, A. 1849, Exp. 50.6 de julio de 1849.

37 AHN. Consejos, 8969, A. 1862, Exp. 478. 17 de febrero de 1862.

${ }^{38}$ Su hijo Antonio Mercader y Tudela heredaría el título de marqués de Malferit, con grandeza de España. AHN. Consejos, 8987, A. 1868, Exp. 634. 4 de mayo de 1868.

${ }^{39}$ Derecho que debió heredar de su abuelo Pascual Vicente Fenollet y Valterra, quien tomó posesión del condado de Olocau en 1771, tras fallecer su padre Genovevo Fenollet. AHN. Consejos, L. 2504, F. 339v. 4 de diciembre de 1771.

40 AHN. Consejos, 8991, A. 1889, Exp. 19. 18 de marzo de 1889.

${ }^{41}$ El padre de ambos, Antonio José Almunia Judici, se había casado en primer lugar con Vicenta Sancho y en segundas nupcias con Juliana Rodríguez Mergelina. AHN. Universidades, 667, Exp. 54.

42 Fueron comisionados a tal efecto por parte de la entidad Francisco de Paula Labayla, consiliario y vicepresidente, y Vicente Marzo, entonces secretario académico. ARASC. Libro de Acuerdos de Juntas Particulares 1846-1863. Juntas 14 y 24 de marzo de 1848.

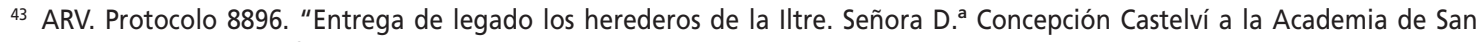
Carlos de esta ciudad", fol. 672v. València, 27 de marzo de 1848. Sobre la donación de estas obras, nuestro estudio reciente incide en la importancia de ellas en el arte valenciano y su relevancia para la colección del Museo de Bellas Artes de València, especialmente el San Sebastián atendido por Santa Irene y su criada de Ribera. PÉREZ-MARTín, Mariángeles. "Women Painters and Academicians: Models and Collections". En: DIÉGUEZ-RODRÍGUEZ, A. et al. Artists as collectors: models and variants. Turnhout (Belgium): Brepols (en prensa).

44 ELIA, Gioia. "Valentín Carderera, el príncipe de Anglona, los marqueses de Jabalquinto y los duques de Uceda: noticia de unas relaciones artísticas y personales", Cartas Hispánicas, 2015, n² 2, p. 1-55.

45 MARTíNEZ PLAZA, Pedro J. "La colección artística de Josefa Marín (1807-1871), condesa viuda de Velle", Ars bilduma, 2017, n० 7, p. 153-166. 
lecciones excepcionales de titularidad femenina en el panorama hispano decimonónico son la de María Josefa Alfonso-Pimentel (1750-1834), duquesa de Osuna, aristócrata ilustrada y mecenas de Goya, con más de 340 pinturas;46 o la gran colección de pintura contemporánea que atesoró junto a su esposo Ángela Pérez de Barradas (18271903), duquesa de Medinaceli, y de Denia y Tarifa, que acumulaba unas seiscientas. ${ }^{47}$ Estudios recientes que confirman la actividad como coleccionistas y mecenas de mujeres de los estamentos nobiliario y cortesano como fue en el siglo XVIII la de Isabel de Farnesio (1692-1766), culta aristócrata italiana, reina consorte de Felipe V. ${ }^{48}$

En el Inventario y justiprecio realizado por el administrador y los albaceas de la marquesa del Ràfol, la colección artística se tasó por un total de 107.240 reales de vellón. Aunque, como ya advertíamos, los precios de venta que alcanzaron en almoneda muchas de las obras superaron con creces la estimación inicial. La identificación de cada una de las piezas con la escueta descripción es una ardua tarea que se prolongará en el tiempo y quizá no sea posible en algunas. Títulos singulares, cuya iconografía no es muy común, como el cuadro "con marco viejo que representa Josué parando el Sol", permiten aventurar su identificación. En este caso, y dado que la obra se encuentra actualmente en el Museo de Bellas Artes de València, podía tratarse del óleo sobre lienzo Josué parando el Sol (ca. 1650), del pintor Esteban March [Fig. 1]. ${ }^{49}$ Yolanda Gil Saura en su estudio sobre la colección del primer marqués de Villatorcas, José Castellví y Alagón (†1722), y de su hijo, Juan Basilio Castelví Coloma (†1754), conde de Cervellón por matrimonio, relaciona esta pintura con el que fuera virrey de Mallorca entre 1691 y 1698. El inventario de las alhajas que Juan Basilio Castelví recibió como herencia paterna al casarse en 1702 con la condesa de Cervellón, contenía setenta y cinco pinturas y cinco láminas grabadas. Entre las cuales, siete lienzos y un apostolado eran del pintor valenciano Esteban March. ${ }^{50}$ Sin embargo, debido -como afirma Gil Saura- a la compleja historia de la dispersión de la colección, desconocemos si la pieza pudo en algún momento ser heredada por Concepción Castellví -con quien compartían apellidoo por algún antepasado vinculado a los marqueses de Villatorcas.

Aunque no podemos detenernos en analizar aquí todas las pinturas de la colección, vemos que abarcan un amplio abanico temático. Es cierto que imperan las de asunto religioso, ${ }^{51}$ pero hay también mitológicas, algún retrato y, sobre todo, naturalezas muertas, flores y frutas. En el coleccionismo valenciano, la temática religiosa que había sido habitual en los siglos anteriores continuó engrosando las colecciones durante el siglo XIX. Como señala Rafael Gil Salinas, las razones que justifican este ascenso eran de distinto signo a las de época precedente. Fue sobre todo la desamortización de los bienes eclesiásticos -de Mendizábal- realizada en 1836 lo que generó un importante mercado artístico donde los coleccionistas valencianos pudieron adquirir piezas a muy buen precio. En muchos casos, tenían escasa importancia consideraciones estéticas, incluso las convicciones religiosas. Si bien, coincidiendo con la Restauración, se detecta en la sociedad un renacimiento del sentimiento religioso. Respecto a los artistas son predominantemente de origen español tanto en las colecciones hispanas como en las valencianas de la época. ${ }^{52}$

\footnotetext{
46 FERNÁNDEZ-QUINTANILLA, Paloma. La duquesa de Osuna: una ilustrada en la corte de Carlos III. Madrid: Doce Calles, 2017.

47 GASCÓN JUSTE, Sonsoles; HERCE, Pablo. Ángela, duquesa de Medinaceli y marquesa de las Navas, su vida, su obra, su tiempo. Madrid: S. Gascón, 1995

48 Sobre la actividad coleccionista de Isabel de Farnesio véase VALDIVIESO, Enrique (com.). Murillo. Pinturas de la colección de Isabel de Farnesio en el Museo del Prado (Fundación Focus, Sevilla, del 20-V al 21-VII de 1996). Sevilla: Fundación Fondo de Cultura de Sevilla, 1996.

Para una breve antología de la historiografía feminista europea y americana sobre el patronazgo femenino y la promoción artística véase GARCÍA PÉREZ, Noelia. "El patronazgo artístico femenino y la construcción de la historia de las mujeres: una asignatura pendiente de los estudios de género". En: BOSCH FIOL, E. et al. Los feminismos como herramienta de cambio social, vol. 1 (Mujeres tejiendo redes históricas, desarrollos en el espacio público y estudios de las mujeres). Palma: Universitat de les Illes Balears, 2006, p. 121-128.

49 Figura 1: Esteban MARCH (València, ca. 1610 - ca. 1668). Josué parando el Sol, ca. 1650-1660. Óleo sobre tela, 135,5 x 192,6 cm. Inv. 612. Museo de Bellas Artes de València.

50 GIL SAURA, Yolanda, 2007-2008 (nota 7), p. 176

${ }^{51}$ Coleccionistas y clientes españoles fueron poco dados a novedades, en la primera mitad del siglo XVII surge el aficionado al arte de la pintura que tiende a crear una colección de temática religiosa instalándola en oratorios y otros lugares de la casa. Formaban así en sus residencias auténticos museos de arte. Junto a la pintura devocional había retratos y otras de asuntos profanos; también empezaron a gozar de éxito las naturalezas muertas y bodegones. CANO DE GARDOQUI GARCíA, José Luis, 2001 (nota 4), p. 140.

52 GIL SALINAS, Rafael, 1994 (nota 5), p. 130.
} 


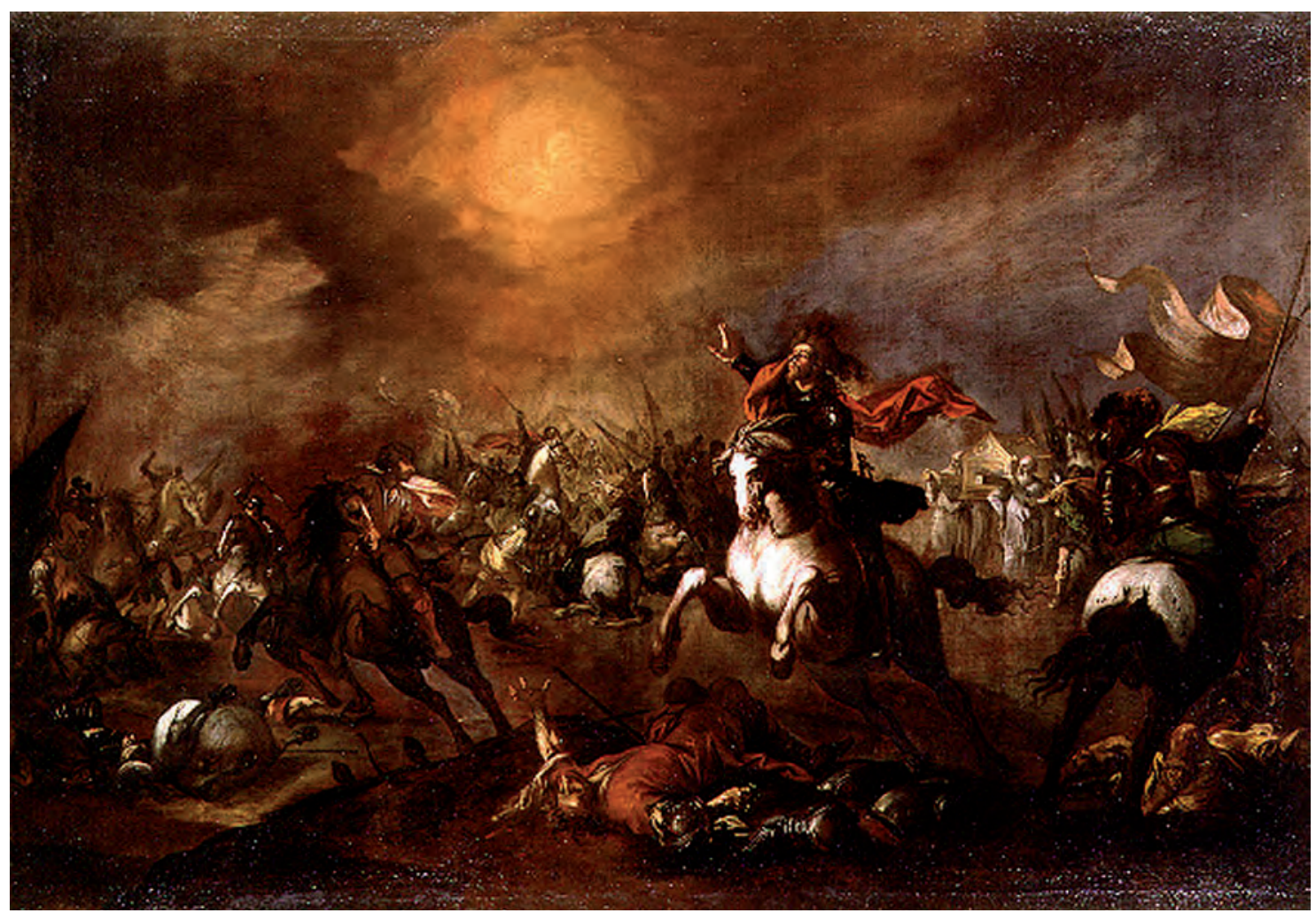

Fig. 1. Esteban March. Josué parando al Sol, ca. 1650-1660. Museo de Bellas Artes de València.

En cuanto a la colección de la marquesa del Ràfol, en el extenso y detallado Inventario las pinturas se describen por estancias, lo que nos permite imaginar el ambiente estético del palacio de los marqueses, que tanta admiración causó a viajeros como Laborde o Ford. ${ }^{53}$ La vivienda era un lugar de exhibición artística que proporcionaba al coleccionista decimonónico un elevado prestigio social. ${ }^{54}$ En el comedor del palacio había cuarenta y tres pinturas, la mayoría bodegones como "una liebre muerta y un capacito de nueces", las dos tablas pequeñas con "dos canastos de flores", y dos lienzos de "dos fruteras, cada una con su Guacamayo", o "un melón cortado, varios racimos de uva, membrillos y otras frutas". Así como, los famosos mariscos tan preciados en la época, "una colección de mariscos"; junto a los típicos paisajes, "un pastor, dos vacas y un ma- cho cabrío". También tenían en el comedor los retratos de los reyes Carlos IV y María Luisa de Borbón, junto a diez cuadros de temática religiosa: representaciones de la Virgen, Nuestra Señora del Rosario, dos religiosos carmelitas descalzos, dos cabezas de fraile, un Venerable, o la Cena del Castillo de Emaús. Aunque la mayoría de las veces no se identifica al autor de la pieza, sí que se menciona a reputados pintores como Orrente, "Nanif", Murillo, Ribera, "Gerónimo Espinosa", "el Basano", "Rafael Ángel" o Zurbarán. Incluso se citan obras realizadas por la propia marquesa que colgaban de las paredes del palacio. Un San Francisco al pastel, que estaba ubicado en la antesala, y un "cuadrito pequeño al pastel con marco dorado y cristal que representa una Purísima de medio cuerpo" situado en el saloncito, una de las estancias más ricas artísticamente.

53 Los textos de ambos viajeros tuvieron gran difusión y suponen una impresión de primera mano sobre las viviendas de la élite y la nobleza de la época en España. LABORDE, Alexandre de. Voyage pittoresque et historique de l'Espagne, 4 vols. París: Imprimerie de Pierre Didot l'ainé, 1806-1820; FORD, Richard. A Handbook for Travellers in Spain and Readers at Home, 2 vols. Londres: John Murray, 1845.

${ }^{54}$ Sobre la vivienda como lugar de exhibición artística véase PÉREZ MATEO, Soledad. "El interior doméstico: retrato del coleccionista del siglo XIX". En: Actas do I Seminário de Investigaçao em Museologia dos Países de Lingua Portuguesa e Espanhola, vol. 1. Oporto: Universidad de Oporto, 2010, p. 353-363. 
El primer cuarto inventariado es el recibidor, allí había ocho cuadros, el más valioso era uno de Pastores y ganado de Orrente tasado en $800 \mathrm{rs} / \mathrm{v}$. El siguiente espacio descrito es la citada antesala, con veintitrés piezas donde había lienzos, tablas y planchas de cobre enmarcadas. Llama la atención que entre esos cuadros se incluya "un mapa de papel del plano moderno de la ciudad de València". Siguiendo el recorrido pasamos al Saloncito en el que registraron cincuenta y seis piezas, muchas de ellas eran tablas, planchas de cobre, algún grabado y sobre todo lienzos, casi todos con marco dorado. Después estaba el comedor que, como hemos mencionado, contenía cuarenta y tres obras. Proseguía adentrándose en el auténtico museo del palacio, la Sala, con sesenta y una piezas tasadas en $73.560 \mathrm{rs} / \mathrm{v}$. Allí se ubicaban los cuadros más preciados, como los lienzos de Ribera, el de Espinosa y el de Murillo que serían donados al Museo de Bellas Artes de València, junto a otros tantos lienzos, tablas y numerosos cuadros en miniatura.

Sorprendente resulta que hubiera una estancia denominada "cuadrera", con cinco piezas. En el "cuarto para escribir" predomina la temática religiosa. Aunque había un Eccehomo y un Jesús Nazareno con la Cruz a cuestas, junto a Santa Teresa desmayada, es llamativo que el resto de representaciones sean figuras femeninas vinculadas a la maternidad: una Virgen abrazando a su hijo, una Purísima Concepción, un San Joaquín con la Virgen dormida, la Virgen con el Niño en la falda y Santa Ana, la Virgen dando de mamar al Niño Jesús, y un San José con el Niño Jesús en brazos. La iconografía de las obras podría sugerir que era la marquesa la que escribía allí. A continuación, en la sala de la chimenea había un cuadro de Un molino harinero rústico y cuatro figuras -recordemos que entre los vínculos patrimoniales que poseía la marquesa había varios molinos-. En la alcoba se describen solo cuatro piezas de temática religiosa, una curiosa "plancha de cobre con marco chapado de concha, adornos de plata y su cristal" que representaba también un Nacimiento. Continuaba "el pasillo del oratorio" con once cuadros, entre ellos el del "marqués del Ràfol vestido de grande uniforme de Maestrante". En ese pasillo se ubicaba también el retrato de la madre Sor Inés de Benigànim, para cuya beatificación fundó una administración con la que sufragar los gastos. Finalizaba el recorrido en el "cuarto de labor de las mujeres" que contenía dos retratos pintados sobre cristal.

Esta breve aproximación a la colección nos confirma que, tal como comentaba el cronista de El Fénix, se trataba de una colección de gran prestigio. Sin duda, estamos ante una de las más importantes en el ámbito valenciano decimonónico. La temática religiosa de las obras y la abundancia de artistas españoles, muchos de ellos valencianos, entre las firmas que se citan era habitual en la época. Las colecciones aristocráticas formadas siglos antes se mantenían en buena parte a finales del siglo XVIII, conjugando en su mayoría el cariz acumulativo fruto de la herencia familiar con el carácter erudito a partir de los encargos de los nuevos propietarios, como probablemente sucedió en este caso. ${ }^{55}$ Los viajeros y cronistas se referían siempre a "la colección del marqués del Ràfol", sin embargo, un análisis de los datos eliminando el sesgo androcéntrico permite afirmar que se trataba de la colección del marqués y de la marquesa del Ràfol. Concepción Castellví Cardona fue una mujer culta, descendiente de uno de los linajes valencianos más antiguos y con mayor peso en la cultura ilustrada local. A pesar de las limitaciones que como mujer marcaron su trayectoria ella también participó del ambiente cultural valenciano en los inicios de la Modernidad. Aficionada desde muy joven a la pintura ingresó como una de las primeras académicas de Bellas Artes en la Academia de San Carlos. Un hecho que debió influir en las adquisiciones de su propia colección de arte.

La biblioteca que formaron -aún pendiente de estudio- ${ }^{56}$ sugiere una tarea compartida también, pues incluye títulos documentados en bibliotecas de otras mujeres aristócratas de esa misma época. ${ }^{57}$ El hallazgo del testamento e inventario de la

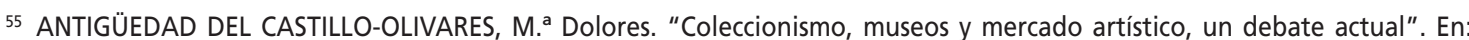
Colecciones, expolio, museos y mercado artístico en España en los siglos XVIII y XIX. Madrid: Editorial Universitaria Ramón Areces, 2011, p. 19.

${ }^{56}$ Entre las bibliotecas valencianas más destacadas de época moderna se encontraba la del citado José de Castelví y Alagón estudiada por FELIPO ORTS, Amparo. "La biblioteca del primer marqués de Villatorcas en Valencia (1722)". En: IGLESIAS RODRÍGUEZ, J. J. et al. Comercio y cultura en la Edad Moderna. Sevilla: Editorial Universidad de Sevilla, 2015, p. 2259-2272. Muy relevante también la compilada por Antonio Folch de Cardona, a cuyo linaje pertenecía la marquesa del Ràfol, que ha sido analizada por GIL SAURA, Yolanda. "Antonio Folch de Cardona (1657-1724). Biografía cultural de un religioso y político, bibliófilo y coleccionista entre Valencia y Viena", Ars Longa, 2014, n²3, p. 173-185.

57 ARIAS DE SAAVEDRA ALÍAS, Inmaculada. "Lectura y bibliotecas de mujeres en la España del siglo XVIII", Cuadernos de Ilustración y Romanticismo, 2017, $n^{\circ}$ 23, p. 57-82; REY CASTELAO, Ofelia. "Las ciudades y los libros en la España de la segunda mitad del siglo XVIII. Una perspectiva provincial en femenino". En: CERVANTES BELLO, F. J. (coord.). Libros y lectores en las sociedades hispanas: España y Nueva España (siglos XVI-XVIII). Puebla: Universidad Autónoma de Puebla, 2016, p. 205-250. 
marquesa aporta una información precisa de cómo era el interior de una vivienda de la nobleza valenciana del siglo XIX, por lo que esperamos que darlo a conocer sea una valiosa herramienta de estudio. Queda pendiente el análisis de las numerosas almonedas que se prologaron durante más de un año, documentos que arrojarán luz sobre la dispersión de la colección artística. Y las descripciones, aunque escuetas, permitirán apuntar el destino de algunas piezas. El ejemplo de la mar- quesa del Ràfol con la localización de su testamento evidencia la necesidad de continuar indagando en los archivos, cuyos documentos arrojan datos que permiten rescatar del olvido sus nombres. Y, con ello, dibujar el devenir histórico de obras que conforman nuestro patrimonio cultural actual. Mientras, la introducción de nombres femeninos en el relato del patronazgo artístico contribuye a conformar un panorama más completo, plural e igualitario del coleccionismo en España.

\section{Anexo}

\begin{tabular}{|c|c|c|}
\hline $\begin{array}{l}N^{\circ} \\
\text { Inv. }\end{array}$ & DESCRIPCIÓN CUADROS 58 & $\begin{array}{l}\text { Reales } \\
\text { de } \\
\text { vellón }\end{array}$ \\
\hline 625 & $\begin{array}{l}\text { Tres cuadros con marcos viejos e iguales uno de los cuales representa a Josué } \\
\text { parando el Sol }\end{array}$ & 140 \\
\hline 626 & Un cuadro viejo que representa a Carlo Magno & 160 \\
\hline 627 & Un cuadro grande antiguo que representa la Casa de Diana & 600 \\
\hline 628 & Otro cuadro grande antiguo que representa varias frutas y una matrona & 240 \\
\hline 629 & Otro cuadro antiguo que representa un campamento & 140 \\
\hline 630 & Otro cuadro antiguo con Pastores y ganado de Orrente & 800 \\
\hline 631 & $\begin{array}{l}\text { Un cuadro con marco dorado que representa a San Francisco Javier predicando a } \\
\text { los Indios }\end{array}$ & 260 \\
\hline 632 & $\begin{array}{l}\text { Otro cuadro con marco dorado que representa un San Bernardo abrazando a } \\
\text { Jesucristo }\end{array}$ & 200 \\
\hline 633 & Otro cuadro con marco dorado que representa a S. Ignacio Francisco de Riccis & 60 \\
\hline 634 & Otro cuadro con marco dorado, retrato de un clérigo después de muerto & 60 \\
\hline 635 & $\begin{array}{l}\text { Otro cuadro de pintura al pastel representa un San Francisco hecho por la Señora } \\
\text { Marquesa }\end{array}$ & 20 \\
\hline 636 & Un cuadro al óleo con marco dorado que representa varias frutas & 200 \\
\hline 637 & Otro cuadro al óleo con marco dorado retrato de un Frayle Carmelita & 80 \\
\hline 638 & $\begin{array}{l}\text { Otro cuadro al óleo con marco dorado que representa la pasión martirizando al } \\
\text { Señor }\end{array}$ & 160 \\
\hline 639 & Otro cuadro sobre tabla que representa una Virgen de las Angustias & 80 \\
\hline 640 & $\begin{array}{l}\text { Un lienzo con marco dorado que representa a San Vicente Ferrer en el acto de } \\
\text { predicar }\end{array}$ & 126 \\
\hline 641 & Otro lienzo con marco dorado que representa el templo de Salomón & 200 \\
\hline 642 & $\begin{array}{l}\text { Una plancha de cobre con marco dorado que representa el nacimiento del niño } \\
\text { Jesús }\end{array}$ & 80 \\
\hline 643 & Otra plancha de cobre con marco dorado que representa la adoración de los Reyes & 100 \\
\hline 644 & Un lienzo con marco que representa la venerable Sor Inés de Benigànim & 80 \\
\hline 645 & Otro lienzo con marco que representa el retrato del Venerable Patriarca & 60 \\
\hline 646 & Otro lienzo con marco que representa la pasión en el paso de la Verónica & 160 \\
\hline 647 & Una tabla con marco dorado que representa un San Cristóval & 300 \\
\hline 648 & Un lienzo con marco dorado que representa la tentación de San Antonio Abad & 100 \\
\hline 649 & Otro lienzo con marco dorado que representa un San Juan Bautista & 100 \\
\hline
\end{tabular}

58 Datos extraídos de ARV. Registros Notariales. Juan Genovés Causa. València, 1848. Protocolo 8896. "Segunda jornada del Inventario de los bienes de la herencia de la llustre Sra. D. ${ }^{a}$ Concepción Castelví", fols. $214 \mathrm{v}$ y ss. Se respeta la ortografía original, pero se modifica la acentuación para su mejor comprensión. 


\begin{tabular}{|c|c|c|}
\hline 650 & $\begin{array}{l}\text { Otro lienzo con marco dorado que representa un pasage de la historia antigua en } \\
\text { que un ganado de corderos negros se transformó en blancos }\end{array}$ & 160 \\
\hline 651 & Otro lienzo con marco dorado que representa el entierro de Jesucristo & 120 \\
\hline 652 & Otro lienzo con marco dorado pequeñito que representa una calavera & 50 \\
\hline 653 & Un mapa de papel del plano moderno de la ciudad de Valencia & 20 \\
\hline 654 & Un cuadro pintado al óleo con marco dorado que representa varias cazas muertas & 300 \\
\hline 655 & $\begin{array}{l}\text { Dos cuadros pintados al óleo con marcos dorados que representan los Santos } \\
\text { Médicos }\end{array}$ & 340 \\
\hline 656 & Otros dos cuadros pequeñitos de piedras moradas & 400 \\
\hline 657 & Otros dos cuadros pintados al óleo con cristal que representa cada uno una rosa & 10 \\
\hline 658 & $\begin{array}{l}\text { Una tabla con marco de madera que representa una Dolorosa al pie de la cruz } \\
\text { abrazando a Jesucristo, y otra tabla con marco dorado que representa una } \\
\text { penitente Magdalena }\end{array}$ & 170 \\
\hline 659 & Un lienzo con marco dorado que representa un San Antonio & 400 \\
\hline 660 & Otro lienzo con marco dorado que representa un Filósofo & 700 \\
\hline 661 & Otro lienzo pequeño con marco dorado que representa un San Francisco de Asís & 50 \\
\hline 662 & Otro lienzo con marco dorado que representa a Jesucristo & 40 \\
\hline 663 & Otro lienzo con marco dorado que representa San Vicente Mártir & 80 \\
\hline 664 & Una tabla pequeña con marco dorado que representa la Resurrección del Señor & 80 \\
\hline 665 & $\begin{array}{l}\text { Dos grabados pequeños con marco dorado y cristales que representa San Luis } \\
\text { Gonzaga y San Estanislao de Kosca }\end{array}$ & 10 \\
\hline 666 & $\begin{array}{l}\text { Dos tablas con medios puntos que representan un Señor con la Cruz a cuestas y } \\
\text { otro Señor haciendo oración en el huerto de Jetsemaní }\end{array}$ & 60 \\
\hline 667 & $\begin{array}{l}\text { Un lienzo grande con marco pintado y dorado que representa Nuestra Señora de } \\
\text { la Luz }\end{array}$ & 2.000 \\
\hline 668 & Una tabla pequeña con marco dorado que representa un San Vicente Ferrer & 60 \\
\hline 669 & $\begin{array}{l}\text { Un lienzo con marco dorado que representa el Martirio de un Santo cortándole la } \\
\text { cabeza }\end{array}$ & 100 \\
\hline 670 & $\begin{array}{l}\text { Dos tablas con inscripciones góticas que representa una Virgen y el } \\
\text { Descendimiento de la Cruz }\end{array}$ & 1.000 \\
\hline 671 & Un lienzo con marco dorado que representa un San José & 120 \\
\hline 672 & Otro lienzo con marco dorado con otro Filósofo & 700 \\
\hline 673 & $\begin{array}{l}\text { Otro lienzo pequeño con marco dorado y cristal que representa la cabeza de un } \\
\text { Eccehomo }\end{array}$ & 120 \\
\hline 674 & Una tabla mediana con marco dorado que representa Nuestra Señora del Pilar & 160 \\
\hline 675 & Otra tabla pequeña con marco dorado con dos claveles & 60 \\
\hline 676 & Un lienzo pequeño con marco dorado que representa San José, la Virgen y el Niño & 50 \\
\hline 677 & $\begin{array}{l}\text { Un lienzo con marco dorado que representa San Juan Evangelista escribiendo la } \\
\text { vida de la Virgen }\end{array}$ & 800 \\
\hline 678 & Otro lienzo con marco dorado mediano que representa San Francisco de Paula & 200 \\
\hline 679 & Otro lienzo con marco dorado con el retrato del Sr. Don Benito Lafiguera & 100 \\
\hline 680 & $\begin{array}{l}\text { Otro lienzo con marco dorado que representa un caballero a la antigua con peluca } \\
\text { blanca jugando con un perrito }\end{array}$ & 500 \\
\hline 681 & $\begin{array}{l}\text { Una tablita pequeña con marco dorado circular que representa un retrato con } \\
\text { montera }\end{array}$ & 20 \\
\hline 682 & Una planchita al pastel que representa la cabeza de San Vicente & 160 \\
\hline 683 & $\begin{array}{l}\text { Una planchita con marco de madera ébano que representa la presentación de la } \\
\text { Virgen al Templo }\end{array}$ & 60 \\
\hline 684 & Un lienzo mediano con marco dorado que representa una Soledad & 100 \\
\hline 685 & $\begin{array}{l}\text { Dos tablas medianas con marcos dorados que representa un San Francisco de Asís } \\
\text { y un San Pascual Baylón }\end{array}$ & 400 \\
\hline 686 & Un lienzo con marco dorado que representa un San Antonio de Padua & 200 \\
\hline
\end{tabular}




\begin{tabular}{|c|c|c|}
\hline 687 & Un lienzo con marco dorado que representa un San Antonio de Padua & 60 \\
\hline 688 & Un lienzo grande con marco dorado que representa una Soledad & 500 \\
\hline 689 & $\begin{array}{l}\text { Un cuadro pequeño pintado sobre cristal con marco dorado que representa la } \\
\text { conversión de la Samaritana }\end{array}$ & 100 \\
\hline 690 & $\begin{array}{l}\text { Un lienzo con marco dorado con el retrato de medio cuerpo de Don Rosalío } \\
\text { Guerau de Arellano }\end{array}$ & 60 \\
\hline 691 & $\begin{array}{l}\text { Un cuadrito pequeño al pastel con marco dorado y cristal que representa una } \\
\text { Purísima de medio cuerpo, obra de la Señora Marquesa }\end{array}$ & 10 \\
\hline 692 & Un lienzo con marco dorado que representa una mesa de juego de naipes & 200 \\
\hline 693 & Una tabla con marco dorado que representa la Cena & 500 \\
\hline 694 & $\begin{array}{l}\text { Dos lienzos con marco dorado que representan la presentación del Niño Jesús al } \\
\text { templo y la huida de la Sagrada Familia a Egipto }\end{array}$ & 300 \\
\hline 695 & $\begin{array}{l}\text { Dos planchas de cobre con marco dorado que representan la una la anunciación } \\
\text { de la Virgen y la otra el Niño Jesús disputando en el Templo }\end{array}$ & 200 \\
\hline 696 & Un lienzo con marco dorado que representa un Nazareno de medio cuerpo & 200 \\
\hline 697 & $\begin{array}{l}\text { Un lienzo con marco negro y cristal que representa una Virgen con un Niño en } \\
\text { brazos y San José }\end{array}$ & 400 \\
\hline 698 & $\begin{array}{l}\text { Un lienzo con marco dorado que representa la aparición de Jesucristo después de } \\
\text { la Resurrección }\end{array}$ & 160 \\
\hline 699 & $\begin{array}{l}\text { Un cuadrito pequeño con marco de madera y cristal que representa una Virgen } \\
\text { dibujado con lápiz }\end{array}$ & 8 \\
\hline 700 & $\begin{array}{l}\text { Una planchita pequeña de cobre con marco dorado que representa una Purísima } \\
\text { Concepción }\end{array}$ & 50 \\
\hline 701 & Un lienzo con marco dorado que representa dos cabezas de Frayle & 40 \\
\hline 702 & Un lienzo con marco dorado que representa un frutero con dos ángeles & 80 \\
\hline 703 & Otro lienzo con marco dorado que representa una leona con sus cachorros & 100 \\
\hline 704 & Otro lienzo con marco dorado que representa dos Religiosos Carmelitas Descalzos & 200 \\
\hline 705 & $\begin{array}{l}\text { Dos lienzos con marcos dorados que representan dos países con dos pasages de la } \\
\text { historia antigua }\end{array}$ & 200 \\
\hline 706 & $\begin{array}{l}\text { Dos lienzos con marcos dorados que representan dos retratos uno de una Señora } \\
\text { disfrazada y el otro de dos Mujeres asomadas a una ventana }\end{array}$ & 240 \\
\hline 707 & Dos lienzos pequeños con marco dorado que representan dos paisajes & 200 \\
\hline 708 & $\begin{array}{l}\text { Otro lienzo grande con marco dorado que representa la Cena del Castillo de } \\
\text { Emaús }\end{array}$ & 1.000 \\
\hline 709 & $\begin{array}{l}\text { Dos cuadros pequeños con marcos dorados que representan dos cabezitas de un } \\
\text { Abogado y Santo hermitaño }\end{array}$ & 200 \\
\hline 710 & $\begin{array}{l}\text { Dos lienzos con marco dorado que representan dos fruteras cada una con su } \\
\text { Guacamayo }\end{array}$ & 600 \\
\hline 711 & Dos lienzos con marcos dorados que representan una colección de mariscos & 500 \\
\hline 712 & $\begin{array}{l}\text { Dos tablas con marco de madera pintada de negro que representan dos floreros } \\
\text { ovalados pintados por Nanif }\end{array}$ & 360 \\
\hline 713 & Dos tablas pequeñas con marco dorado que representan dos canastos de flores & 60 \\
\hline 714 & $\begin{array}{l}\text { Un lienzo larguilongo con marco dorado que representa una flor col, dos cabezas } \\
\text { de ajos, varios peces y dos manzanas }\end{array}$ & 100 \\
\hline 715 & $\begin{array}{l}\text { Un lienzo con marco dorado que representa una liebre muerta y un capacito con } \\
\text { nueces }\end{array}$ & 6.000 \\
\hline 716 & $\begin{array}{l}\text { Dos planchas de cobre con marcos dorados que representan la una varias frutas } \\
\text { flores y pescados y la otra varias flores y una bandeja de dulces secos }\end{array}$ & 160 \\
\hline 717 & Dos lienzos pequeños con marcos dorados que representan dos cabezas & 160 \\
\hline 718 & $\begin{array}{l}\text { Un lienzo grande con marco dorado que representa un paisaje con un pastor, dos } \\
\text { vacas y un macho cabrío }\end{array}$ & 160 \\
\hline 719 & $\begin{array}{l}\text { Otro lienzo cuadrilongo con marco dorado que representa un melón cortado, } \\
\text { varios racimos de uva, membrillos y otras frutas }\end{array}$ & 80 \\
\hline 720 & $\begin{array}{l}\text { Otro lienzo con marco de madera que representa un medio cuerpo de un } \\
\text { Venerable }\end{array}$ & 60 \\
\hline
\end{tabular}




\begin{tabular}{|c|c|c|}
\hline 721 & $\begin{array}{l}\text { Otro lienzo con marco dorado que representa la aparición sobre su sepulcro de } \\
\text { San Domingo de la Calzada a su madre cuando estaba orando por él }\end{array}$ & 200 \\
\hline 722 & Otro lienzo con marco dorado que representa a Nuestra Señora del Rosario & 100 \\
\hline 723 & $\begin{array}{l}\text { Un grabado iluminado con marco de madera y cristal que representa una Dolorosa } \\
\text { y los quince misterios }\end{array}$ & 10 \\
\hline 724 & $\begin{array}{l}\text { Un lienzo con marco dorado floreado que representa una mesa de cocina con } \\
\text { varios útiles de ella, frutas, aves y verduras }\end{array}$ & 80 \\
\hline 725 & $\begin{array}{l}\text { Una tabla pequeña con marco dorado que representa una Virgen con manto } \\
\text { blanco }\end{array}$ & 40 \\
\hline 726 & Un lienzo con marco dorado que representa un canasto con frutas y alcarchofas & 120 \\
\hline 727 & $\begin{array}{l}\text { Dos lienzos con marcos dorados que representan el uno una fuente con granadas } \\
\text { y manzanas y el otro un paisaje con cabras montesas y un perro guardándolas }\end{array}$ & 200 \\
\hline 728 & $\begin{array}{l}\text { Dos lienzos con marcos dorados que representan el uno varios pescados y el otro } \\
\text { un paisaje sobre el cual hay extendida una servilleta con pan, peras y otras frutas }\end{array}$ & 160 \\
\hline 729 & $\begin{array}{l}\text { Dos lienzos con marcos de madera pintados de blanco de figura ovalada que } \\
\text { representan los retratos de medio cuerpo de los Reyes Carlos cuarto y María Luisa } \\
\text { de Borbón }\end{array}$ & 60 \\
\hline 730 & $\begin{array}{l}\text { Un paisaje de lienzo sin marco que representa unos labradores y ganado vacuno y } \\
\text { lanar }\end{array}$ & 60 \\
\hline 731 & $\begin{array}{l}\text { Un lienzo con marco de madera pintada de negro que representa San José, la } \\
\text { Virgen, el Niño y varios Ángeles }\end{array}$ & 40 \\
\hline 732 & $\begin{array}{l}\text { Dos lienzos grandes con marcos dorados que representan dos floreros dentro de } \\
\text { jarros }\end{array}$ & 800 \\
\hline 733 & Otro lienzo con marco dorado que representa a San Pedro meditando & 1.000 \\
\hline 734 & $\begin{array}{l}\text { Otro lienzo con marco dorado que representa un paisaje con una Santa penitente } \\
\text { que tiene alrededor unos Angelitos }\end{array}$ & 400 \\
\hline 735 & $\begin{array}{l}\text { Quince tablas circulares pequeñitas con marco dorado que representan los quince } \\
\text { misterios }\end{array}$ & 300 \\
\hline 736 & $\begin{array}{l}\text { Un lienzo con marco dorado que representa un San Pedro en oración y el Ángel } \\
\text { enseñándole el infierno }\end{array}$ & 800 \\
\hline 737 & $\begin{array}{l}\text { Una tabla chata cuadrilonga con marco dorado que representa San Vicente Ferrer } \\
\text { de medio cuerpo }\end{array}$ & 160 \\
\hline 738 & Un lienzo grande con marco dorado que representa el Sacrificio de Isach & 1.500 \\
\hline 739 & $\begin{array}{l}\text { Un lienzo con marco dorado que representa un clérigo de medio cuerpo con un } \\
\text { rosario en las manos }\end{array}$ & 120 \\
\hline 740 & Otro lienzo que representa un Santo de medio cuerpo con un libro en las manos & 500 \\
\hline 741 & $\begin{array}{l}\text { Otro lienzo que representa Santa Teresa en Oración cuando se le apareció San } \\
\text { José y la Virgen }\end{array}$ & 400 \\
\hline 742 & $\begin{array}{l}\text { Otro lienzo con marco dorado chato cuadrilongo que representa un Cristo tendido } \\
\text { en una Sábana y la Virgen con cuatro evangelistas }\end{array}$ & 800 \\
\hline 743 & $\begin{array}{l}\text { Otro lienzo con marco dorado que representa una Virgen con los niños Jesús y San } \\
\text { Juan }\end{array}$ & 2.000 \\
\hline 744 & Otro lienzo con marco dorado que representa un Cristo en la agonía & 800 \\
\hline 745 & Otro lienzo con marco dorado que representa una Santa Bárbara de medio cuerpo & 300 \\
\hline 746 & $\begin{array}{l}\text { Otro lienzo con marco dorado que representa un Nazareno con la Cruz a cuestas } \\
\text { de medio cuerpo }\end{array}$ & 800 \\
\hline 747 & $\begin{array}{l}\text { Un lienzo grande con marco dorado que representa una Virgen y el Niño de } \\
\text { cuerpo entero obras de Murillo }\end{array}$ & 3.000 \\
\hline 748 & Una tabla con marco dorado que representa el Martirio de San Sebastián & 2.500 \\
\hline 749 & $\begin{array}{l}\text { Una tabla con marco dorado que representa un San Gerónimo haciendo } \\
\text { penitencia }\end{array}$ & 2.500 \\
\hline 750 & $\begin{array}{l}\text { Otra tabla con marco dorado que representa una Santa haciendo oración y dos } \\
\text { ángeles sosteniendo una corona de espinas sobre un altar }\end{array}$ & 2.500 \\
\hline 751 & Otra tabla con marco dorado que representa los apóstoles San Pedro y San Pablo & 2.500 \\
\hline 752 & $\begin{array}{l}\text { Un lienzo grande con marco dorado que representa un San Sebastián muerto } \\
\text { después del martirio obra del célebre Ribera }\end{array}$ & 35.000 \\
\hline
\end{tabular}




\begin{tabular}{|c|c|c|}
\hline 753 & $\begin{array}{l}\text { Una tabla pequeña con marco dorado que representa una Virgen de medio } \\
\text { cuerpo sentada con un Niño en brazos }\end{array}$ & 200 \\
\hline 754 & $\begin{array}{l}\text { Dos tablas pequeñas con marcos dorados que representan la una, una Virgen de } \\
\text { medio cuerpo con el Niño en brazos, y la otra la Caridad con tres niños en brazos }\end{array}$ & 400 \\
\hline 755 & $\begin{array}{l}\text { Un lienzo grande con marco dorado que representa San Pedro Pascual en el acto } \\
\text { de celebrar misa y el niño Jesús ayudándole obra de Don Gerónimo Espinosa }\end{array}$ & 8.000 \\
\hline 756 & $\begin{array}{l}\text { Una pizarra negra con marco de madera negro que representa Jesucristo } \\
\text { crucificado en el Monte Calvario obra del Basano }\end{array}$ & 800 \\
\hline 757 & $\begin{array}{l}\text { Una tabla con marco dorado que representa una Virgen vestida a la antigua con } \\
\text { corona y campo ovalado dorado }\end{array}$ & 400 \\
\hline 758 & $\begin{array}{l}\text { Un lienzo pequeño con marco dorado que representa una Virgen de medio } \\
\text { cuerpo con la cabeza del Niño }\end{array}$ & 320 \\
\hline 759 & $\begin{array}{l}\text { Un lienzo con marco dorado que representa el boceto de San Miguel obra de } \\
\text { Rafael Ángel }\end{array}$ & 600 \\
\hline 760 & Otro lienzo con marco dorado que representa un Eccehomo de medio cuerpo & 700 \\
\hline 761 & $\begin{array}{l}\text { Una tabla con marco dorado que representa un Santo leyendo y tocando una } \\
\text { calavera }\end{array}$ & 600 \\
\hline 762 & $\begin{array}{l}\text { Otra tabla mediana con marco dorado que representa la Adoración de los Santos } \\
\text { Reyes }\end{array}$ & 1.000 \\
\hline 763 & $\begin{array}{l}\text { Un lienzo pequeño con marco dorado que representa un San Antonio Abad de } \\
\text { medio cuerpo }\end{array}$ & 200 \\
\hline 764 & $\begin{array}{l}\text { Otro lienzo pequeño con marco dorado que representa una Dolorosa de medio } \\
\text { cuerpo }\end{array}$ & 300 \\
\hline 765 & $\begin{array}{l}\text { Otro lienzo grande con marco dorado que representa una Purísima Concepción de } \\
\text { cuerpo entero obra del célebre Zurbarán }\end{array}$ & 800 \\
\hline 766 & $\begin{array}{l}\text { Dos tablas ovaladas con marcos de madera pintados de negro que representa dos } \\
\text { jarros con flores obra de Gerónimo Nanif que hacen juego con los dos del } \\
\text { saloncito }\end{array}$ & 360 \\
\hline 767 & $\begin{array}{l}\text { Nueve cuadritos en miniatura con sus marquitos que representan uno San } \\
\text { Francisco de Paula, otro una Virgen, tres de ellos un retrato de cada uno, otro los } \\
\text { cuatro evangelistas, otro la Virgen, el Niño y un Ángel, otro el retrato de la } \\
\text { Venerable Sor Inés de Benigànim y el otro la Virgen del Pilar }\end{array}$ & 200 \\
\hline 768 & $\begin{array}{l}\text { Un cuadro con marco dorado y realces con su cristal y un ramo de flores pintado } \\
\text { sobre papel }\end{array}$ & 150 \\
\hline 769 & Otro cuadro pequeño con su Eccehomo sobre tabla y dorado & 350 \\
\hline 770 & $\begin{array}{l}\text { Un cuadro con marco dorado y cristal que representa un Cristo clavado en la Cruz } \\
\text { y la Magdalena a sus pies }\end{array}$ & 500 \\
\hline 771 & $\begin{array}{l}\text { Una plancha de cobre con marco dorado que representa el Niño Jesús sostenido } \\
\text { por su madre pisando el dragón }\end{array}$ & 300 \\
\hline 772 & $\begin{array}{l}\text { Un lienzo pequeño con marco dorado que representa una Virgen de los } \\
\text { Desamparados }\end{array}$ & 160 \\
\hline 773 & $\begin{array}{l}\text { Una plancha de cobre con marco dorado que representa a Santa Teresa } \\
\text { desmayada y un Ángel que la sostiene }\end{array}$ & 50 \\
\hline 774 & $\begin{array}{l}\text { Una tabla que representa la Santísima Virgen abrazando a su hijo después de } \\
\text { crucificado }\end{array}$ & 80 \\
\hline 775 & $\begin{array}{l}\text { Un cuadro apaisado que representa a Jesús Nazareno con la Cruz a cuestas con } \\
\text { marco de madera pintado y cristal }\end{array}$ & 2 \\
\hline 776 & $\begin{array}{l}\text { Un cuadro pequeño con estampa que representa un Eccehomo con marco de } \\
\text { nogal pulimentado y cristal }\end{array}$ & 2 \\
\hline 777 & $\begin{array}{l}\text { Otro cuadro pequeño con estampa bordada que representa la Purísima } \\
\text { Concepción }\end{array}$ & 2 \\
\hline 778 & $\begin{array}{l}\text { Otro cuadro pequeño sobre tabla con marco dorado que representa San Joaquín } \\
\text { con la Virgen dormida sobre su pecho }\end{array}$ & 200 \\
\hline 779 & $\begin{array}{l}\text { Una plancha de cobre con marco dorado que representa la Virgen con el Niño en } \\
\text { la falda y Santa Ana preparando la cuna }\end{array}$ & 160 \\
\hline 780 & $\begin{array}{l}\text { Una tabla con marco dorado que representa la Virgen dando de mamar al niño } \\
\text { Jesús }\end{array}$ & 160 \\
\hline 781 & $\begin{array}{l}\text { Otra tabla pequeña con marco negro y cristal que representa a San José con el } \\
\text { Niño Jesús en los brazos }\end{array}$ & 40 \\
\hline
\end{tabular}




\begin{tabular}{|l|l|r|}
\hline 782 & $\begin{array}{l}\text { Un cuadro con marco dorado que representa un molino harinero rústico y cuatro } \\
\text { figuras }\end{array}$ & 100 \\
\hline 783 & Una tabla con marco dorado que representa una Virgen con el Niño en los brazos & 800 \\
\hline 784 & $\begin{array}{l}\text { Una plancha de cobre con marco negro ochavado y adornos dorados al fuego que } \\
\text { representa San Antonio de Padua }\end{array}$ & 500 \\
\hline 785 & $\begin{array}{l}\text { Una plancha de cobre con marco chapado de concha, adornos de plata y su cristal } \\
\text { que representa un nacimiento }\end{array}$ & 340 \\
\hline 786 & Una plancha con marco dorado que representa una oración de los Santos Reyes & 200 \\
\hline 787 & Un cuadro sobre lienzo que representa la adoración de los Santos Reyes & 80 \\
\hline 788 & Otro cuadro con marco colorado que representa la Resurrección del Señor & 80 \\
\hline 789 & $\begin{array}{l}\text { Otro cuadro con marco colorado que representa a Jesucristo con dos apóstoles en } \\
\text { el Castillo de Mans }\end{array}$ & 80 \\
\hline 790 & Otro cuadro con marco colorado que representa el nacimiento del niño Dios & 80 \\
\hline 791 & Un cuadro sobre lienzo que representa a Fray Miguel de Arándiga Templario & 60 \\
\hline 792 & Un cuadro sobre tabla retrato de la madre Sor Inés de Benigànim & 40 \\
\hline 793 & $\begin{array}{l}\text { Un cuadro sobre tabla con marco dorado que representa San José, la Virgen y el } \\
\text { Niño Jesús }\end{array}$ & 160 \\
\hline 794 & $\begin{array}{l}\text { Otro cuadro con marco dorado que representa la Virgen, el Niño, San José, San } \\
\text { Juan y un Ángel }\end{array}$ & 80 \\
\hline 795 & Un retrato sobre lienzo con marco dorado y cristal del Señor Marqués del Ràfol \\
vestido de grande uniforme de Maestrante & 60 \\
\hline 796 & $\begin{array}{l}\text { Otro retrato sobre lienzo con marco dorado de la Señora Marquesa esposa del } \\
\text { anterior D. José Almunia }\end{array}$ & 70 \\
\hline 797 & Un lienzo con marco dorado que representa a San Francisco de Asís & 40 \\
\hline 798 & Dos retratos pintados sobre cristal con marcos dorados y grabados & 30 \\
\hline
\end{tabular}


